\title{
Analiza modelowa układu stomatognatycznego przy odbudowach z zastosowaniem mostów protetycznych
}

\begin{abstract}
Streszczenie. Wymogiem klinicznym dla stałych uzupełnień protetycznych jest takie projektowanie ich konstrukcji, aby w czasie funkcji żucia nie doprowadzały do urazowych przeciążeń. Celem jest analiza naprężeń i przemieszczeń, występujacych w trakcie obciążenia zgryzowego w zespole zębowo-zębodołowym i strukturach kostnych żuchwy oraz zastosowanych w tym układzie mostach. Wizualizacja biomechaniczna modeli pozwoliła ocenić wzajemne relacje pomiędzy rozległością przęsła mostu a uwarunkowaniami anatomicznymi tkanek podłoża protetycznego.

Abstract. Clinical requirement for fixed restorations is the design of the construction to during chewing function do not lead to traumatic overload. The aim is to analyze the stresses and displacements that occur during loading the occlusal on the team dental-alveolar and the jaw bone structures and used in this system bridges. Biomechanical visualization to models allowed to assess interaction between the extent of the structure of the bridge and the determinants of tissue anatomical of prosthetics substrate. (Model analysis of the stomatognathic system restorations using prosthetic bridges).
\end{abstract}

Słowa kluczowe: biomechanika, modelowanie, MES, mosty protetyczne.

Keywords: biomechanics, modelling, FEA, prosthetic bridges

\section{Wstęp}

Podstawowym wymogiem klinicznym jest takie projektowanie konstrukcji mostów protetycznych, aby w czasie funkcji żucia nie doprowadzały do urazowych przeciążeń zgryzowych wynikających ze zmienionej tymi uzupełnieniami biomechaniki narządu żucia. Osadzenie w jamie ustnej mostu zaburza fizjologiczne wielopunktowe przeniesienie obciążeń wyzwalanych podczas aktu żucia. Jeżeli zespołach zębowo-zębodołowych i zębach filarowych nastąpi niebezpieczne wytężenie tkanek tzn. naprężenia zredukowane i przemieszczenia przekroczą dopuszczalne wartości, może to doprowadzić do przekroczenia progu fizjologicznej wydolności. Obciążenia wypadkowe łuków zębowych zaopatrzonych mostami protetycznymi uzależnione są od: rozmieszczenia zębów filarowych w stosunku do przęsła mostu, kierunku przebiegu osi długich zębów filarowych, umiejscowienia mostu w łuku zębowym oraz długości i szerokości przęsła mostu. Obserwacja przypadków klinicznych i niepowodzeń związanych z zaburzeniami biomechaniki stałych uzupełnień protetycznych potwierdza celowość numerycznego modelowania oraz ich optymalizacji na etapie projektowania. W szczególności problem ten dotyczy projektowania rozległych mostów protetycznych, szczególnie w bocznym odcinku żuchwy, gdzie w czasie żucia działają główne i największe obciążenia zgryzowe.

Celem pracy jest analiza modelowa stanu wytężenia występującego w trakcie obciążenia zgryzowego w zespole zębowo-zębodołowym i kości żuchwy oraz stosowanych w tym układzie mostach protetycznych w odcinku bocznym.

\section{Materiał i metoda}

Przedmiotem badań były mosty protetyczne uzupełniające braki zębowe w bocznych odcinkach żuchwy. Badane były cztery warianty rozwiązań konstrukcyjnych mostów o różnym zasięgu przęsła: most 43045, most 430046, most 4300047, most 43000048. Konstrukcje te wykonywane były w trzech różnych technologiach tj. jako: mosty ceramiczne, mosty licowane ceramiką na podbudowie metalowej oraz mosty korundowe. Modelowanie rozwiązania konstrukcyjnego uzupełnienia prowadzone było na wirtualnym modelu żuchwy, który opracowano na podstawie procedury odwzorowania badanego obiektu w warunkach in vitro oraz CT $[1,2]$. Automatycznie generowano krzywe ograniczające wyselekcjonowane obszary (szkliwo, zębina, miazga, ozębna, kość korowa, kość gąbczasta, ceramika, stop NiCrMo). Następnie przeprowadzono statystyczne opracowanie tych krzywych. Procedura tworzenia wirtualnych modeli została opracowana na potrzeby pracy. Wykorzystano programy dedykowane do rekonstrukcji przestrzennych: e-Film, Amira. Przeprowadzono rekonstrukcję przestrzenną obejmującą łączenie modeli płaskich i generowanie powierzchni trójwymiarowych. Rekonstrukcje przestrzenne odpowiadały strukturom anatomicznym i konstrukcjom protetycznym (rys.1) [3].
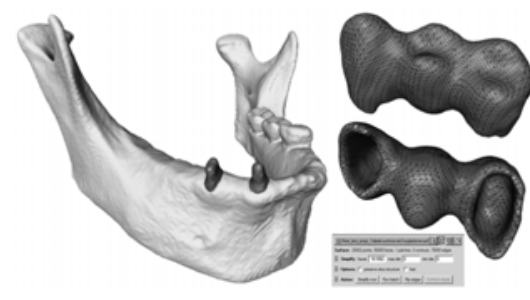

Rys.1. Rekonstrukcja modelu żuchwy z filarami protetycznymi oraz konstrukcja dwubrzeżnego mostu protetycznego

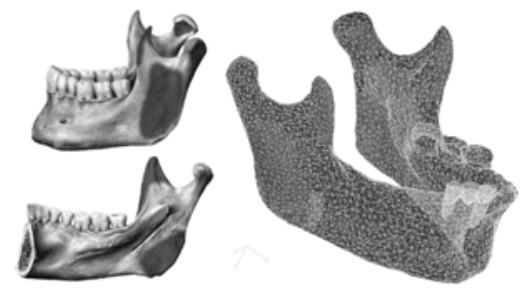

Rys.2. Model anatomiczny i numeryczny żuchwy z wprowadzonymi utwierdzeniami na powierzchniach przyczepów mięśni żuciowych

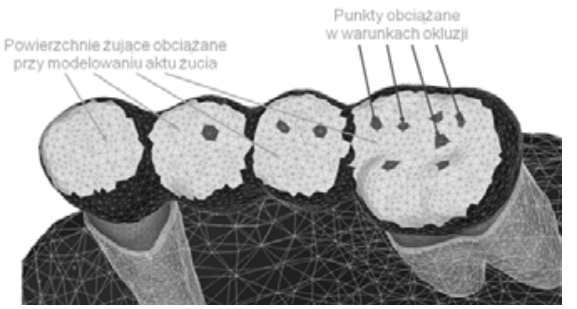

Rys.3. Strefy obciążeń modelowych w okluzji centralnej oraz w warunkach aktu żucia

Aby wykonać symulacje numeryczne wprowadzono utwierdzenia i obciążenia modeli. Do zadania utwierdzeń 
wykorzystano powierzchnie mięśni żuciowych (rys.2) [4,5]. warunkach okluzji oraz w akcie żucia (rys.3) [6].

\section{Wyniki badań}

Analizę przeprowadzono na podstawie rozkładów naprężeń: w konstrukcjach mostów protetycznych, w zębach filarowych, w tkankach przyzębia oraz w dwuwarstwowej strukturze żuchwy.

\section{Analiza naprężeń w modelach mostu 43045}

Dla warunków okluzji centralnej zestawiono rozkłady naprężeń zredukowanych dla mostów z trzech różnych materiałów konstrukcyjnych osadzonych wirtualnie na takim samym podłożu protetycznym, przy takich samych utwierdzeniach i obciążeniach (rys.4). Stwierdzono, że charakter rozkładu naprężeń (przechodzenie trajektorii głównych) jest we wszystkich trzech przypadkach taki sam. Dla poszczególnych mostów naprężenia zawierają się w przedziale 0-1,10 MPa. W konstrukcjach mostów stwierdzono małe naprężenia, przy czym nieznaczne spiętrzenia naprężeń występowały w przęśle od strony dośluzówkowej pomiędzy koroną filaru 43 i repliką korony zęba $44-0,25-1 \mathrm{MPa}$, w strefie brzeżnej koron 43 i $45-$ 0,15-0,63 MPa oraz w strefie kontaktów zębowych - 0,4$1,10 \mathrm{MPa}$. W wartościach i zasięgu spiętrzeń naprężeń $\mathrm{W}$ strefie brzeżnej koron występują różnice związane z rodzajem materiału konstrukcyjnego, przy czym największe spiętrzenia stwierdzono w moście $z$ ceramiki korundowej na koronie zęba 43 od strony językowej i wynoszą: 0,63 MPa.

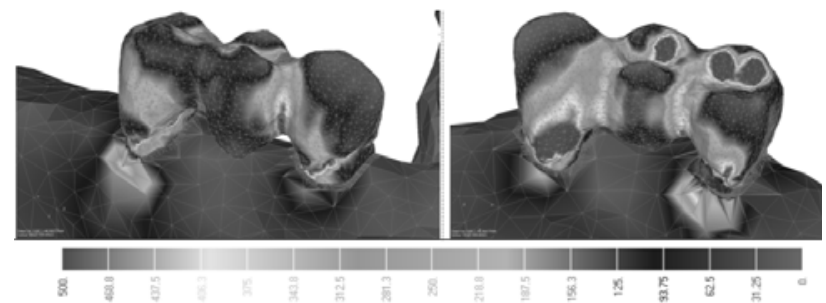

Rys.4. Rozkłady naprężeń zredukowanych w warunkach okluzji dla mostu 43045 wykonanego z ceramiki korundowej: a) widoki od strony policzkowej, b) widoki od strony językowej

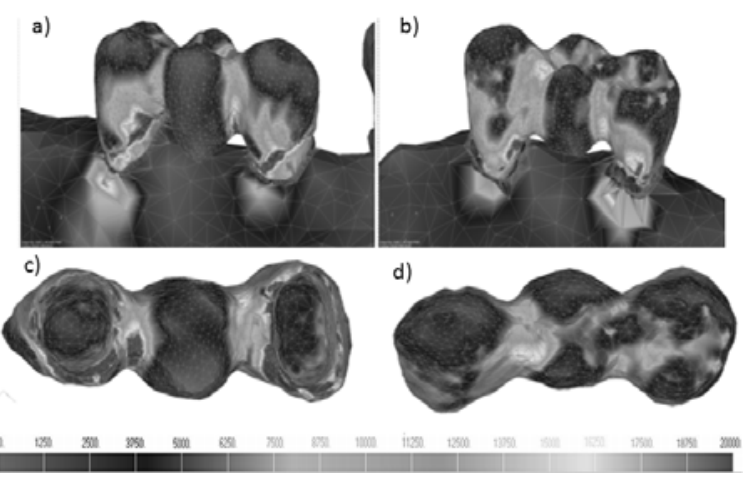

Rys.5. Rozkłady naprężeń zredukowanych w warunkach żucia dla mostu 43045 wykonanego z ceramiki korundowej: a) widok od strony policzkowej, b) widok od strony językowej, c) widok od strony dośluzówkowej, d) widok od strony powierzchni żującej

W warunkach żucia zestawiono rozkłady naprężeń zredukowanych dla mostów z trzech różnych materiałów konstrukcyjnych osadzonych wirtualnie na takim samym podłożu protetycznym, przy takich samych utwierdzeniach i obciążeniach (rys.5 i 6). Stwierdzono, że charakter rozkładu naprężeń był we wszystkich trzech przypadkach taki sam. Dla poszczególnych mostów naprężenia mieściły się w przedziale 0-20,0 MPa. Spiętrzenia naprężeń w strefie brzeżnej koron wynosiły 16-20 MPa, na stopniach zębów filarowych - 18-20 MPa, na łączeniu przęsła z koroną zęba 43 od strony dośluzowej - 16-20 MPa (rys.5). W strefie obciążonych powierzchni żujących nie występowały spiętrzenia naprężeń, a wartości naprężeń zredukowanych mieściły się w przedziale 3-4 MPa.

Rodzaj zastosowanego materiału konstrukcyjnego nie wpływa na charakter rozkładu naprężeń. W przypadku mostu trójpunktowego żuchwa była bardzo nieznacznie obciążona, wzrost naprężeń występował na stopniach zębów filarowych oraz na łączeniu przęsła z koroną zęba 43 (rys.5).

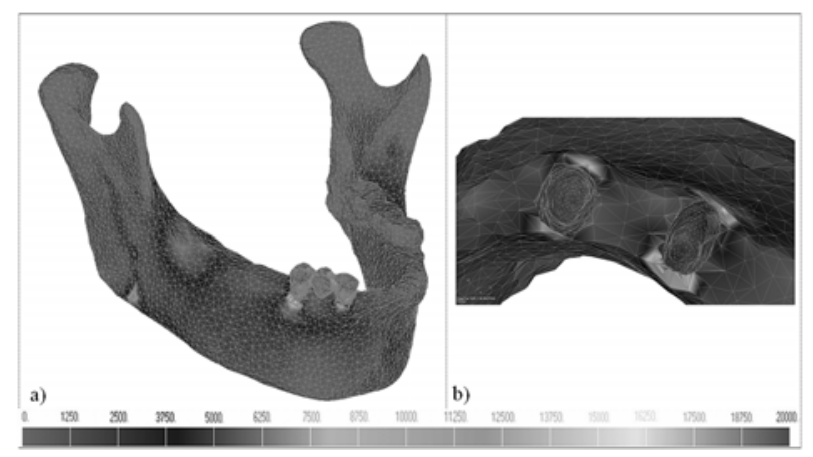

Rys.6. Rozkład naprężeń zredukowanych w warunkach żucia w żuchwie z mostem 43045: a) widok ogólny, b) widok zębodołów zębów filarowych

\section{Analiza naprężeń w modelach mostu 430046}

Dla warunków żucia zestawiono rozkłady naprężeń zredukowanych dla mostów z trzech różnych materiałów konstrukcyjnych osadzonych wirtualnie na takim samym podłożu protetycznym, przy takich samych utwierdzeniach i obciążeniach. Charakter rozkładu naprężeń był we wszystkich trzech przypadkach taki sam. W analizowanych mostach występowały różnice wartości naprężeń w zależności od materiału konstrukcyjnego. W zębach filarowych spiętrzenia naprężeń występowały w strefie wykonanego stopnia - 16-24 MPa. W korzeniach zębów filarowych podwyższone naprężenia występowały głównie od strony policzkowej (8 MPa) i językowej (7 MPa). W warunkach żucia w analizowanych modelach stwierdzono tłumienie naprężeń w ozębnej zębów filarowych (rys.7). W kontakcie zęba filarowego z ozębną naprężenia wynoszą 5$10 \mathrm{MPa}$, natomiast $\mathrm{w}$ zębodołach tych zębów naprężenia przyjmują wartości 0,5-3 MPa.

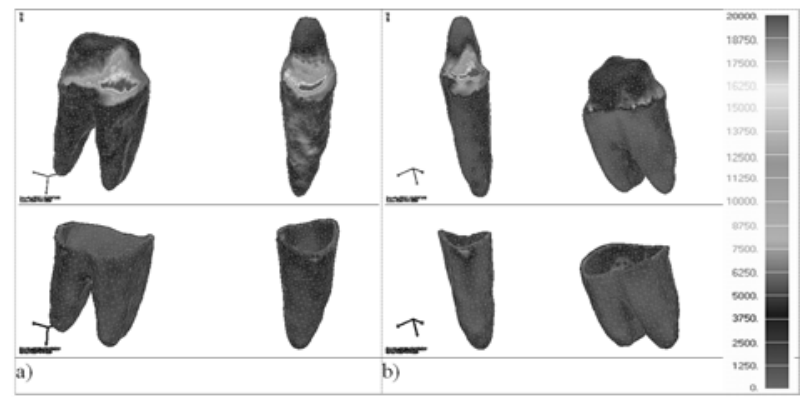

Rys.7. Rozkłady naprężeń zredukowanych $\mathrm{w}$ warunkach żucia $\mathrm{w}$ ozębnej i zębach filarowych mostu korundowego 430046: a) widoki od strony policzkowej, b) widoki od strony językowej

\section{Analiza naprężeń w modelach mostu 4300047}

Dla warunków żucia wyznaczono rozkłady naprężeń zredukowanych dla mostów z trzech różnych materiałów konstrukcyjnych osadzonych wirtualnie na takim samym podłożu protetycznym, przy takich samych utwierdzeniach i obciążeniach. Stwierdzono, że charakter rozkładu naprężeń jest we wszystkich trzech przypadkach taki sam. W analizowanych mostach wystąpiły różnice wartości 
naprężeń w zależności od materiału konstrukcyjnego. W warunkach żucia w analizowanych modelach widoczne jest tłumienie naprężeń w ozębnej zębów filarowych (rys.8).
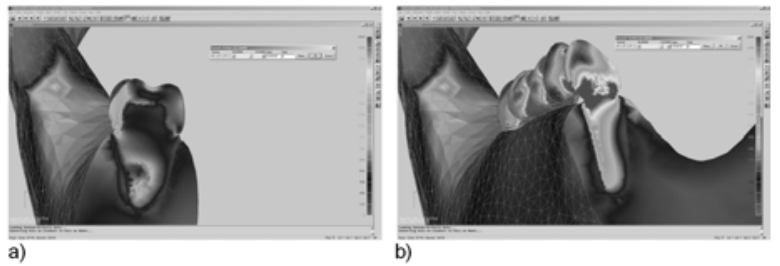

Rys.8. Rozkłady naprężeń w warunkach żucia w przekrojach przez osie długie zębów filarowych $w$ modelu $z$ mostem $z$ ceramiki tłoczonej: a) filar 47 , b) filar 43

\section{Analiza naprężeń w modelach mostu 43000048}

Dla warunków żucia zestawiono rozkłady naprężeń zredukowanych dla mostów z trzech różnych materiałów konstrukcyjnych osadzonych wirtualnie na takim samym podłożu protetycznym, przy takich samych utwierdzeniach i obciążeniach. Stwierdzono, ze charakter rozkładu naprężeń był we wszystkich trzech przypadkach taki sam. W zębach filarowych mostu ceramicznego wystąpiły spiętrzenia naprężeń w strefie wykonanego stopnia: na zębie 43 - $94 \mathrm{MPa}$, na zębie 48 - $51 \mathrm{MPa}$. W przypadku mostu lanego licowanego ceramiką na zębach filarowych spiętrzenia naprężeń w strefie wykonanego stopnia wynosiły: na zębie 43 - $78 \mathrm{MPa}$, na zębie $48-53,4 \mathrm{MPa}$, a w zębach filarowych przy zastosowaniu mostu z ceramiki korundowej spiętrzenia naprężeń w strefie wykonanego stopnia są następujące: na zębie $43-70,0 \mathrm{MPa}$, na zębie 48 - $56,8 \mathrm{MPa}$. W korzeniach zębów filarowych stwierdzono duże asymetryczne naprężenia: od strony policzkowej, dla zęba 43 do $25 \mathrm{MPa}$ i dla zeba 48 do $18 \mathrm{MPa}$, a od strony językowej dla zęba 43 do $9 \mathrm{MPa}$ i dla zęba 48 do $7 \mathrm{MPa}$. Ponadto w zębie 48 występuje spiętrzenie naprężeń w bifurkacji korzenia - 21,0 MPa. W warunkach żucia $w$ analizowanych modelach (dla wszystkich materiałów konstrukcyjnych) widoczne są spiętrzenia naprężeń w ozębnej zębów filarowych: dla aparatu zawieszeniowego zęba 43 - 18-23 MPa, a dla aparatu zawieszeniowego 48 - 15-18 MPa (rys.9).

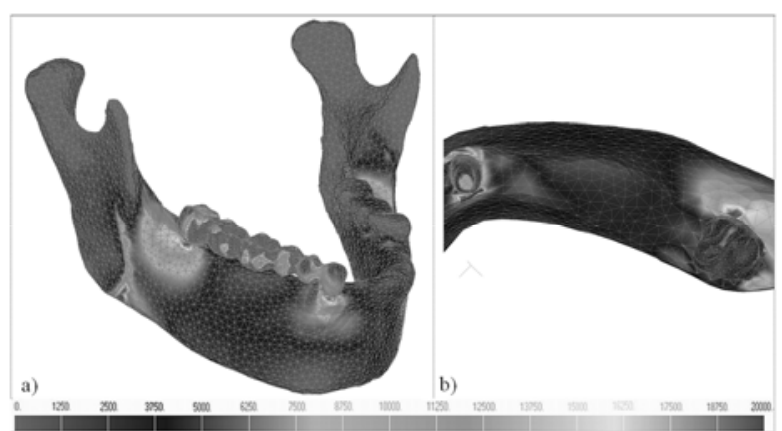

Rys.9. Rozkład naprężeń zredukowanych $w$ warunkach żucia w żuchwie z mostem 43000048 z ceramiki korundowej: a) widok ogólny, b) widok zębodołów zębów filarowych

Obciążenie mostów w warunkach żucia stymuluje duże naprężenia w całej strukturze żuchwy. Występują spiętrzenia naprężeń w bezpośredniej strefie zębów filarowych (do 22,0 MPa) oraz w okolicy kątów żuchwy (do 25,0 MPa). Rozkłady naprężeń w żuchwie są takie same dla wszystkich rodzajów materiałów konstrukcyjnych, z których wykonano mosty.

Rozkład naprężeń w przypadku tego mostu dyskwalifikuje takie rozwiązanie $w$ warunkach klinicznych z uwagi na ugięcie przęsła mostu oraz nadmierne obciążenie przyzębia. Przeniesienie obciążeń przez ząb przedtrzonowy w warunkach wytężenia skutkuje wystąpieniem stref wytężenia na powierzchni żującej oraz w tkankach twardych korzenia zęba od strony policzkowej - $50 \mathrm{MPa}$. Pomimo znacznego obciążenia - komora zęba i kanał korzeniowy są odciążone - wynika to z anatomicznego kształtu zęba i budowy histologicznej. Występuje również wyraźny spadek naprężeń w ozębnej, który skutkuje zmniejszeniem naprężeń w żuchwie $(0,5 \mathrm{MPa})$.

Dyskusja

W warunkach okluzji i żucia konstrukcje mostów protetycznych są obciążane odpowiednio: siłami w kontaktach okluzyjnych lub naciskami jednostkowymi (w zależności od konsystencji pokarmu) na powierzchniach żujących. Obciążenia te powodują określone rozkłady naprężeń i przemieszczeń w konstrukcji uzupełnienia terapeutycznego, w zębach filarowych, w tkankach przyzębia oraz w żuchwie.

Zastosowana w pracy metoda prowadzenia analizy wytrzymałościowo - konstrukcyjnej przy zastosowaniu mostów w bocznym odcinku żuchwy miała na celu:

- Ocenę konstrukcji zastosowanych mostów protetycznych na podstawie wyznaczenia stref maksymalnych naprężeń zredukowanych, w których mogą być przekroczone wartości naprężeń dopuszczalnych oraz maksymalnych przemieszczeń i odkształceń, które mogą powodować stan niebezpieczny dla tej konstrukcji.

- Ocenę przyzębia zarówno w aspekcie wyznaczenia stref spiętrzenia naprężeń, które moga powodować przekroczenie progu fizjologicznej wydolności tkanek, jak również w aspekcie wskazania stref niedociążenia, które mogą powodować procesy zanikowe w obrębie części zębodołowej żuchwy.

$\mathrm{Na}$ podstawie modelowania, symulacji i analiz przeprowadzonych $w$ ramach niniejszej pracy można stwierdzić, że uzyskane wyniki umożliwiają optymalizację projektowania mostu protetycznego. Do optymalizacji wyznaczono i przyjęto następujące kryteria:

- funkcjonalności uzupełniania terapeutycznego,

- wytrzymałości konstrukcji mostu (ocena stref wytężenia materiału konstrukcyjnego, dopuszczalne ugięcie przęsła mostu na jego długości),

- kryterium anatomicznych parametrów podłoża protetycznego,

- kryterium maksymalnych dopuszczalnych naprężeń i przemieszczeń w zębach filarowych oraz w strukturze części zębodołowej żuchwy,

-kryterium maksymalnych dopuszczalnych spiętrzeń na stopniach przydziąsłowych,

- kryterium zginania i wyważania zębów filarowych,

- kryterium dopuszczalnych naprężeń i przemieszczeń w szparze ozębnej,

- kryterium minimalnych naprężeń i przemieszczeń w strefie podłoża protetycznego.

Procedure analizy przeprowadzono na odwzorowanym tomograficznie podłożu protetycznym indywidualnego pacjenta - czym wyróżnia się opracowana strategia działania od przedstawianych w piśmiennictwie i dotychczas stosowanych metod realizowanych w oparciu o modele obiektów rzeczywistych o uproszczonych kształtach zębów, korzeni zębów lub żuchwy. Przy tego typu modelowaniu numerycznym tkanek US w literaturze pomijana była ozębna [7]. Analizowanym uzupełnieniom protetycznym również nadawano przybliżone formy geometryczne z uwagi na trudności w uzyskaniu skomplikowanej geometrii i aplikacji do modeli numerycznych $[8,9]$. Nowością zastosowanej procedury było rozpatrywanie relacji mechanicznych i biomechanicznych w kompleksowym modelu numerycznym uzupełnienie protetyczne - żuchwa z zastosowaniem programu do analiz wytrzymałościowych. 
Autorski charakter przeprowadzonych analiz polegał na transformacji struktur dicom na bryłowe modele numeryczne, modelowaniu kontaktu mostu i podłoża protetycznego oraz kontaktu w strukturach tkankowych. Należy również dodać, że przeprowadzona w pracy kompleksowa analiza wytrzymałościowa dotyczyła obiektów przestrzennych w całości. W dotychczasowym piśmiennictwie podawane są wyniki badań przeprowadzanych analiz numerycznych obiektów przestrzennych na podstawie rozkładów naprężeń w określonych przekrojach płaskich [10,11].

Przystosowany do metody badań i wykorzystany w badaniach własnych program posiada szerokie spektrum możliwości w zakresie analizy obiektu. W przeprowadzonych w pracy symulacjach i analizach starano się o wykorzystanie tych możliwości do oceny procedur klinicznych. Wykonane w pracy rozkłady naprężeń, przemieszczeń i odkształceń dają możliwość oceny stref wytężenia konstrukcji terapeutycznej oraz struktur biologicznych w warunkach wirtualnych.

Podsumowując wyniki badań i analiz poniżej przedstawiono własne wskazania do optymalizacji mostów w bocznym odcinku żuchwy, i skonfrontowano z wynikami innych autorów [12].

Przemieszczenia i odkształcenia w konstrukcjach terapeutycznych rozważano w zakresie:

- odkształceń sprężystych czyli takich, które po ustąpieniu działania obciążenia powodują powrót konstrukcji do stanu początkowego,

- trwałych plastycznych deformacji przęsła mostu dyskwalifikujących uzupełnienie,

- zmęczenia materiału konstrukcyjnego (jego destrukcji w wyniku powtarzających się przeciążeń w czasie użytkowania) co zagraża funkcji uzupełnień protetycznych.

Dla wszystkich rodzajów mostów w warunkach okluzj występowały niewielkie spiętrzenia naprężeń w strefie kontaktów zębowych w zakresie 0,4-2,2 MPa. W literaturze podawane są czasy trwania okluzji $0,10-0,12 \mathrm{~s}$ oraz 0,25 $0,30 \mathrm{~s}$, a także porównywalne jak uzyskane w pracy wartości nacisków (1 MPa) [6].

Analiza stref niebezpiecznych w konstrukcjach mostów oraz dopuszczalne wartości naprężeń na zginanie dla materiałów konstrukcyjnych [13,14], zgodnie z normą ANSI/ADA No 12 (ISO 1567), pozwala na sformułowanie opinii, iż w warunkach klinicznych następujące konstrukcje mostów nie powinny być stosowane:

- mosty ceramiczne 4300047 z uwagi na wytężenia materiału w przewężeniach przęsła mostu 44-45 i 45-46 oraz pomiędzy przęsłem, a koroną zęba 43 ,

- mosty lane licowane ceramiką 4300047 w strefie przewężenia przęsła mostu 44-45 i 45-46 zbliżają się do stanu wytężenia i z tego względu stosowanie ich związane jest z ryzykiem odpryskiwania ceramiki licującej od metalowej podbudowy,

- mosty 43000048 z ceramiki i lane licowane ceramiką z uwagi na wytężenie materiału w przewężeniach przęsła mostu 44-45, 45-46 i 47-48,

- mosty 43000048 z ceramiki korundowej w strefie przewężenia przęsła mostu 45-46 gdyż są na granicy stanu wytężenia materiału.

Otrzymane wyniki potwierdzają wagę prawidłowego wykonania stopnia przydziąsłowego: klinicznie - na zębach filarowych oraz technicznie w moście w warunkach laboratoryjnych. W wyniku niewłaściwego rozwiązania konstrukcyjnego (kształtu, braku łagodnych przejść, błędów wykonawstwa i błędów osadzenia) nadmierne spiętrzenie naprężeń w rejonie stopnia może decydować o niepowodzeniu leczenia protetycznego.

\section{Wnioski}

1. Rodzaj materiału konstrukcyjnego w niewielkim stopniu wpływa na charakter rozkładu naprężeń w przypadku mostów krótkich. Im dłuższe przęsło mostu tym wyraźniejszy jest wpływ materiału konstrukcyjnego.

2. Wielkości i kształty korzeni zębów filarowych oraz ich zamocowanie w wyrostku w zasadniczy sposób wpływają na wartości nacisków kontaktowych, które są przekazywane na strukturę żuchwy.

3. Rozległość przęsła mostu uwarunkowana jest względami anatomicznymi podłoża protetycznego pacjenta i wynika z dopuszczalnych naprężeń, które nie przekroczą progu fizjologicznej wytrzymałości tkanek ozębnej.

\section{LITERATURA}

[1] Rocha E.P., et al., Zirconia-based dental crown to support a removable partial denture: a three-dimensional finite element analysis using contact elements and micro-CT data, Comput Methods Biomech Biomed Engin., 18 (2015), nr.16, 1744-1752

[2] Nakamura K., et al., Dental application of novel finite element analysis software for three-dimensional finite element modeling of a dentulous mandible from its computed tomography images, Proc Inst Mech Eng H., 227 (2013), nr.12, 1312-1318

[3] Santos Filho P.C., Soares P.V., Reis B.R., Veríssimo C., Soares C.J., Effects of threaded post placement on strain and stress distribution of endodontically treated teeth, Braz Oral Res., 27 (2013), nr.4, 305-310

[4] Marcián P., Borák L., Valášek J., Kaiser J., Florian Z., Wolff J., Finite element analysis of dental implant loading on atrophic and non-atrophic cancellous and cortical mandibular bone - a feasibility study, J Biomech., 47 (2014), nr.16, 3830-3836

[5] Gačnik F., Ren Z., Hren N.I., Modified bone density-dependent orthotropic material model of human mandibular bone, Med Eng Phys., 36 (2014), nr.12, 1684-1692

[6] Dejak B., Młotkowski A., A comparison of stresses in molar teeth restored with inlays and direct restorations, including polymerization shrinkage of composite resin and tooth loading during mastication, Dent Mater., 31 (2015), nr.3, 77-87

[7] Murakami N., Wakabayashi N., Finite element contact analysis as a critical technique in dental biomechanics: a review, $J$ Prosthodont Res., 58 (2014), nr.2, 92-101

[8] Thompson M.C., Field C.J., Swain M.V., The all-ceramic, inlay supported fixed partial denture. Part 3. Experimental approach for validating the finite element analysis, Aust Dent J., 57 (2012), nr.1, 23-30

[9] Thompson M.C., Field C.J., Swain M.V., The all-ceramic, inlay supported fixed partial denture. Part 2. Fixed partial denture design: a finite element analysis, Aust Dent J., 56 (2011), nr.3, 302-311

[10] Thompson M., et al., The all-ceramic, inlay supported fixed partial denture. Part 5. Extended finite element analysis validation, Aust Dent J., 58 (2013), nr.4, 434-441

[11]Kermanshah H., Bitaraf T., Geramy A., Finite Element Analysis of IPS Empress II Ceramic Bridge Reinforced by Zirconia Bar, $J$ Dent., 9 (2012), nr.4, 196-203

[12] Tuna M., Sunbuloglu E., Bozdag E., Finite element simulation of the behavior of the periodontal ligament: a validated nonlinear contact model, J Biomech., 47 (2014), nr.12, 28832890

[13]Dittmer M.P., Borchers L., Stiesch M., Kohorst P., Stresses and distortions within zirconia-fixed dental prostheses due to the veneering process, Acta Biomater., 5 (2009), nr.8, 3231-3239

[14]Choi A.H., Matinlinna J., Ben-Nissan B., Effects of micromovement on the changes in stress distribution of partially stabilized zirconia (PS-ZrO2) dental implants and bridge during clenching: a three-dimensional finite element analysis, Acta Odontol Scand., 71 (2013), nr.1, 72-81

Autorzy: dr n. med. Wojciech Ryniewicz, Uniwersytet Jagielloński, Collegium Medicum, Wydział Lekarski, Katedra Protetyki Stomatologicznej, ul. Montelupich 4, 31-155 Kraków, E-mail: wojciech@ryniewicz.pl, dr hab. inż. Anna M. Ryniewicz, prof. AGH, Uniwersytet Jagielloński, Collegium Medicum, Wydział Lekarski, Katedra Protetyki Stomatologicznej, ul. Montelupich 4, 31-155 Kraków, E-mail: anna@ryniewicz.pl. 